\title{
Various Aspects of Tiagabine Effectiveness as Add-on Therapy in Patients with Refractory Epilepsy
}

\author{
Ekaterina Viteva, Zahari Zahariev \\ Department of Neurology, Faculty of Medicine, Medical University of Plovdiv, Plovdiv, Bulgaria
}

Corresponding author: Ekaterina Viteva, Department of Neurology, Faculty of Medicine, Medical University of Plovdiv, 66 Peshtersko shosse St., 4000 Plovdiv; E-mail: eiviteva@abv.bg; Tel.: +359887752235

Received: 24 Dec 2018 Accepted: 30 July 2019 Published: 31 March 2020

Citation: Viteva E, Zahariev Z. Various aspects of tiagabine effectiveness as add-on therapy in patients with refractory epilepsy. Folia Med (Plovdiv) 2020;62(1):59-64. doi: 10.3897/folmed.62.e47762.

\begin{abstract}
The aim of the present study was to investigate various aspects of tiagabine (TGB) effectiveness in Bulgarian patients with drug-resistant epilepsy. This open, prospective study recruited the patients with epilepsy attending the Clinic of Neurology at the University Hospital of Plovdiv, Bulgaria. The patients completed diaries about the seizure frequency, severity, and adverse events. There were regular documented visits at 3 or 6 months during the first year of treatment with TGB and at 6 months or 1 year afterwards, with dynamic assessment of seizure frequency, severity, adverse events, and EEG recordings. TGB was applied as an add-on treatment in 43 patients (24 males, mean age 39 years). There was relatively mild and transient dynamic improvement of seizure severity, satisfactory seizure frequency reduction in 32.6\% of participants, stable mean seizure frequency reduction (40-50\%) from month 6 to month 24 and a stable response rate (52.3-50\%) during the same period. New seizure types (myoclonic, myoclonic-atonic) occurred in 2 patients. The final clinical efficacy was higher in patients with initial monotherapy. There were adverse events (dizziness/vertigo, sedation, memory impairment, loss of appetite and weight, confusion, psychosis, insomnia, transient diplopia, lymphadenomegaly, rash, nausea, depression, anxiety, tremor of hands, unstable gait, legs edema, thrombocytopenia, cervical muscles tightening) in $26.19 \%$ of patients. In conclusion, TGB treatment is associated with low and transient improvement of seizure severity, good and stable improvement of seizure frequency, possible worsening of seizure control, possible appearance of new seizure types, and acceptable safety and tolerability.
\end{abstract}

\section{Keywords}

tiagabine, epilepsy, efficacy, tolerability, adverse events

\section{INTRODUCTION}

Tiagabine (TGB) is a newer generation antiepileptic drug (AED) which enhances GABA activity. It has been approved as an add-on therapy drug for patients with drug-resistant partial epilepsy. The main efficacy outcome from the randomized, double-blind, placebo-controlled, and open-prospective studies, reported by investigators, is seizure frequency that varies from $42 \%$ to $92 \%$ in respondents, from
$10 \%$ to $75 \%$ in seizure free patients, and lack of efficacy in $8.7 \%$ to $12.6 \% .^{1-15}$ The highest efficacy was reported in patients with simple partial seizures compared to those with complex partial and partial seizures with secondary generalization. ${ }^{7-9,14,15}$ Attention has not been focused on seizure severity, as well the correlation of seizure frequency and severity dynamics with demographics and clinical findings. There has been only one study on the effectiveness of TGB monotherapy in patients with drug-resistant partial seizures with or without secondary generalization in Bulgaria, 
the results of which confirmed its satisfactory efficacy and tolerability. ${ }^{16}$ Therefore, the conduction of an open, prospective study on various aspects of effectiveness of add-on therapy with TGB in Bulgarian patients with drug-resistant epilepsy will provide additional useful data for the medical practice.

\section{AIM}

To perform an open, prospective study on various aspects of TGB effectiveness in Bulgarian patients with drug-resistant epilepsy.

\section{PATIENTS AND METHODS}

The study is open, prospective, with a possibility of using available detailed retrospective information about some participants. The study recruited patients with epilepsy from the patients attending the Clinic of Neurology at the University Hospital in Plovdiv, Bulgaria for a regular examination in cases of unsatisfactory seizure control or for adverse events from treatment.

All study procedures were performed after obtaining ethical approval from the local Ethics Committee at the Medical University of Plovdiv. All patients were acquainted with the study design and signed an informed consent form before participating in the study procedures. The following inclusion criteria were used: 1 . A signed informed consent form; 2 . Consent of the patient and relatives about giving the required information and medical records; 3 . Age $\geq$ 18 years; 4. Diagnosis of epilepsy; 5 . Good compliance of patients to recommended treatment; 6 . A stable dose of concomitant AEDs in the recent 3 months; 7 . A period of prospective observation of at least 3 months; 8 . Completed diary about seizure frequency, severity, and adverse events; 10. Regular documented visits at 3 or 6 months during the first year of treatment and at 6 months or 1 year afterwards, with dynamic assessment of seizure frequency, severity, adverse events, and EEG recordings. The criteria for AEDs choice were in conformity with the National Drug Agency-approved indications.

Data were collected by a trained neurologist specialized in epilepsy through an examination of the patients' medical documentation and a detailed interview on the disease onset, heredity, concomitant diseases, type and etiology of epilepsy, seizure type, frequency and severity, treatment with AEDs, efficacy of TGB, adverse events from treatment. Seizure frequency dynamics was based on patients' seizure diaries. Seizure severity was estimated on the basis of information about seizure duration, traumatism during seizures, duration of consciousness loss, severity of postictal manifestations. Adverse events from treatment were assessed as type, severity (mild, moderate, severe), and duration based on reports from patients and relatives, a standardized interview based on a version of the Liverpool Adverse Events profile validated for Bulgaria by Kuzmanova et al. ${ }^{17}$, a physical and neurological status examination at every visit.

Data were analysed using STATA (Stata Corp., College Station, TX, USA) and SPSS (Statistical Package for the Social Sciences) version 13.0 (SPSS Inc., Chicago, IL, USA). The results for quantitative variables were expressed as means \pm SE (standard error) and the results for qualitative variables - in percentages. The principal outcomes were clinical efficacy (effect on seizure frequency and severity, treatment duration and reasons for withdrawal, new seizure types, treatment changes), and tolerability (adverse events). The association of dynamics in seizure frequency and severity with demographics, and clinical findings was tested by means of $\chi^{2}$-test, F-test and Z-test. The level of significance was set at $p<0.05$.

Table 1. Clinical characteristics of patients on treatment with TGB

\begin{tabular}{|c|c|c|c|}
\hline Clinical characteristics & $\mathbf{N}$ & $p(\%)$ & SE \\
\hline \multicolumn{4}{|l|}{ Seizure type } \\
\hline - simple partial seizures & 1 & 2.3 & - \\
\hline - complex partial seizures & 2 & 4.7 & - \\
\hline \multicolumn{4}{|l|}{ - partial seizures with secondary } \\
\hline generalization & 23 & 53.5 & 7.7 \\
\hline - generalized tonic-clonic seizures & 1 & 2.3 & - \\
\hline - partial and generalized seizures & 16 & 37.2 & 7.46 \\
\hline \multicolumn{4}{|l|}{ Etiology of epilepsy } \\
\hline - idiopathic & 3 & 7.0 & - \\
\hline $\begin{array}{l}\text { - symptomatic (traumatic, } \\
\text { vascular, inflammatory, tumor, }\end{array}$ & & & \\
\hline $\begin{array}{l}\text { perinatal pathology, hippocampal } \\
\text { sclerosis) }\end{array}$ & 18 & 41.9 & \\
\hline - unknown & 22 & 51.2 & 7.71 \\
\hline \multicolumn{4}{|l|}{ Neurological status } \\
\hline - normal & 30 & 69.8 & 7.08 \\
\hline - with focal neurological signs & 13 & 30.2 & 7.08 \\
\hline \multicolumn{4}{|l|}{ Recent seizure frequency } \\
\hline - 1-11 seizures/ year & 1 & 2.3 & - \\
\hline - $1-3$ seizures/ month & 12 & 27.9 & 6.92 \\
\hline - 1-6 seizures / week & 24 & 55.8 & 7.66 \\
\hline - daily & 6 & 14.0 & 5.35 \\
\hline \multicolumn{4}{|l|}{ Recent seizure severity } \\
\hline - mild & 15 & 34.9 & 7.35 \\
\hline - severe & 28 & 65.1 & 7.35 \\
\hline
\end{tabular}

\section{RESULTS}

The total number of patients diagnosed with epilepsy who attended the Clinic of Neurology between 2003 and 2016 was 1259 (both in- and outpatients). TGB was received by 43 patients ( 24 males) 19-67 years of age (mean age 
$39.1 \pm 1.88)$. The onset of epilepsy varied from 1 month to 62 years of age, mean age onset $18.76 \pm 2.25$ years. The mean epilepsy duration varied from 1 to 45 years, mean duration - 20.74 \pm 1.81 years. The observation continued from 1 to 84 months (mean duration $20.15 \pm 3.53$ months). The mean initial TGB dosage was $35.0 \pm 1.08 \mathrm{mg} / \mathrm{d}$. The clinical characteristics of study participants are presented in Table $\mathbf{1}$.

We did not find significant differences in the percentage of patients without improvement of seizure severity up to the 24 th month of treatment. There was a gradual decrease of the percentage of participants with seizure severity reduction between month 6 and month 24 (16.7\% at 6 months, $12.9 \%$ at 12 months, $6.3 \%$ at 24 months). Because of the small number of patients who continued TGB treatment after 24 months they were not included in the statistical analysis. We came to the conclusion about a mild and transient improvement of seizure severity by treatment with TGB. There was no correlation of seizure severity dynamics with the initial seizure severity at 6,12 , and 24 months of treatment $\left(\chi^{2}=3.33, \chi^{2}=0.33\right.$, and $\chi^{2}=$ 0.31 , respectively) ( $p>0.05$,). Seizure severity improvement did not correlate with TGB dosage $(\mathrm{p}>0.05)(\mathrm{F}=0.84)$, but correlated with the initial seizure frequency $(p<0.05)\left(\chi^{2}=\right.$

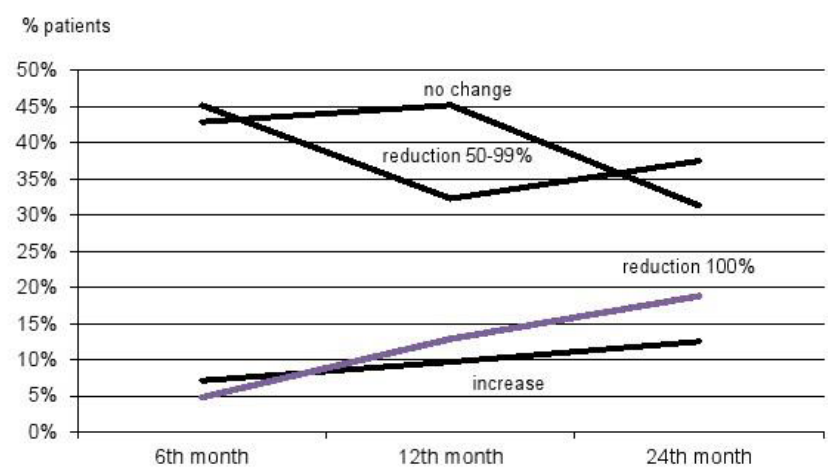

Figure 1. Seizure frequency dynamics during treatment with TGB.

$3.33 ; r=0.31)$. There was seizure severity reduction only in patients with high monthly $-2(16.7 \%)$ and high weekly -5 $(21.7 \%)$ seizure frequency.

The assessment of seizure frequency up to the 24th month of TGB treatment is presented in Table 2.

The most significant improvement of seizure frequen- cy was at 6 months of treatment followed by retention of a high response rate of about $50 \%$ and gradual increase of the percentage of patients without seizures (Table 2). The tendency of seizure frequency dynamic changes during the 24 months of treatment is shown in Fig. 1. The statistical analysis of results confirmed that there was no significant decrease in seizure frequency between month 6 and month 12 month $(p>0.05, Z=0.105)$ and between month 6 and month 24 ( $p>0.05, Z=0.82$ ). We found the following dynamics in the mean seizure frequency reduction $-40 \%$ at 6 months, $39 \%$ at 12 months, and $50 \%$ at 24 months. Therefore, regarding seizure frequency, the efficacy of TGB was good and stable for the study period.

Seizure frequency dynamics correlated moderately with initial seizure frequency at 6 months $\left(p<0.01, \chi^{2}=11.34\right.$, $p<0.001, r=0.52)$ and at 12 months of study $\left(p>0.05, \chi^{2}\right.$ $=4.46, p=0.052, r=0.35$ ), lack of improvement being observed more frequently in patients with higher initial seizure frequency. Seizure frequency improvement did not correlate with TGB dosage $(p>0.05)$.

At the end of the study, seizure frequency increased in $7(16.3 \%)$ participants, there was no or unsatisfactory improvement (seizure frequency reduction $<50 \%$ ) in 22 $(51.2 \%)$ patients. Of fourteen respondents $(32.6 \%)$, seven (16.3\%) had seizure reduction of $50 \%$ to $75 \%, 5(11.6 \%)$ had seizure reduction of less than $75 \%$, and two $(4.7 \%)$ were without seizures. The final seizure frequency reduction correlated moderately only with initial mono- or polytherapy $(p<0.05, r=-0.30)-$ all 7 participants with seizure frequency increase were with initial polytherapy, while of the 14 respondents $50 \%$ were on initial polytherapy. The final seizure frequency reduction did not correlate with any other clinical or demographic findings.

There was modification of the seizure type in a 47-yearold participant with partial seizures with secondary generalization - myoclonic and myoclonic-atonic seizures were described for the first time at 12 months of treatment. That resulted in TGB substitution with levetiracetam.

In $26(60.5 \%)$ study participants, TGB treatment was terminated for various reasons: 1 . Adverse events from treatment in 7 (16.3\%) patients; 2. Lack of efficacy, transient efficacy or increased seizure frequency in 12 (27.9\%) patients; 3. A combination of adverse events and lack of efficacy in 3 (7\%) patients; 4 . Administrative reasons (difficulties with drug prescription or finding the drug in pharmacies) in 4 (9.3\%) patients.

In 9 patients, TGB was stopped very early (before 6

Table 2. Seizure frequency assessment during treatment with TGB

\begin{tabular}{lccccc}
\hline & \multicolumn{4}{c}{ Seizure frequency dynamics } & Total \\
\cline { 2 - 4 } & $\begin{array}{c}\text { No change } \\
\mathbf{N}(\boldsymbol{p} \%)\end{array}$ & $\begin{array}{c}\text { Reduction 50-99\% } \\
\mathbf{N}(\boldsymbol{p} \%)\end{array}$ & $\begin{array}{c}\text { Reduction 100\% } \\
\mathbf{N}(\boldsymbol{p} \%)\end{array}$ & $\begin{array}{c}\text { Increase } \\
\mathbf{N}(\boldsymbol{p} \%)\end{array}$ & $\mathbf{N}(\boldsymbol{p} \%)$ \\
\hline $\mathbf{6}$ months & $18(42.9 \%)$ & $19(45.2 \%)$ & $3(7.1 \%)$ & $2(4.8 \%)$ & $42(100.0 \%)$ \\
$\mathbf{1 2}$ months & $14(45.2 \%)$ & $10(32.3 \%)$ & $3(9.7 \%)$ & $4(12.9 \%)$ & $31(100.0 \%)$ \\
$\mathbf{2 4}$ months & $5(31.3 \%)$ & $6(37.5 \%)$ & $2(12.5 \%)$ & $3(18.8 \%)$ & $16(100.0 \%)$ \\
\hline
\end{tabular}


Table 3. Adverse events from TGB treatment

\begin{tabular}{|c|c|c|c|c|c|}
\hline Adverse event & $\begin{array}{c}\text { Number of } \\
\text { patients }\end{array}$ & $\begin{array}{l}\text { Dosage } \\
(\mathrm{mg} / \mathrm{d})\end{array}$ & Severity & TGB termination & Duration \\
\hline \multirow{2}{*}{ Dizziness/vertigo } & 1 & 40 & Mild-moderate & No & 360 days \\
\hline & 1 & 50 & Moderate & Yes & 120 days \\
\hline \multirow{3}{*}{ Sedation } & 1 & 30 & Severe & Yes & 90 days \\
\hline & 1 & 40 & Severe & Yes & 90 days \\
\hline & 1 & 40 & Moderate & Decreased dose & 300 days \\
\hline Memory impairment & 1 & 30 & Severe & Yes & 13 days \\
\hline \multirow{2}{*}{ Loss of appetite and weight } & 1 & 40 & Mild-moderate & Yes & 90 days \\
\hline & 1 & 60 & Severe & No & 360 days \\
\hline Transient diplopia & 1 & 40 & Mild-moderate & No & 360 days \\
\hline \multirow{2}{*}{ Confusion } & 1 & 30 & Severe & Yes & 13 days \\
\hline & 1 & 40 & Severe & Yes & 90 days \\
\hline Psychosis & 1 & 40 & Severe & Yes & 90 days \\
\hline \multirow{2}{*}{ Insomnia } & 1 & 30 & Severe & Yes & 13 days \\
\hline & 1 & 40 & Severe & Yes & 90 days \\
\hline Lymphadenomegaly & 1 & 20 & Severe & Yes & 30 days \\
\hline Cervical muscles tightening & 1 & 40 & Severe & Yes & 90 days \\
\hline Legs edema & 1 & 40 & Severe & Yes & 90 days \\
\hline Thrombocytopenia & 1 & 40 & Severe & Yes & 90 days \\
\hline \multirow{2}{*}{ Rash } & 1 & 40 & Severe & Yes & 30 days \\
\hline & 1 & 30 & Severe & Yes & 90 days \\
\hline Nausea & 1 & 60 & Severe & Yes & 30 days \\
\hline Depression & 1 & 45 & Mild & No & 90 days \\
\hline Anxiety & 1 & 45 & Mild & No & 90 days \\
\hline Tremor of hands & 1 & 30 & Severe & Yes & 90 days \\
\hline Unstable gait & 1 & 20 & Severe & No & 180 days \\
\hline
\end{tabular}

months of treatment); at 12 months of treatment, PGB was stopped in another 11 patients, and at 24 months - in another 6 patients. Therefore, the percentage of patients continuing TGB treatment gradually decreased, i.e. the retention rate was $86.05 \%$ at 6 months, $60.47 \%$ at 12 months, and $46.51 \%$ at 24 months.

The total duration of TGB treatment was 859 months. The total duration of effectiveness was 596 months, therefore TGB was effective in $69.38 \%$ of the treatment time of all patients. The mean effectiveness duration was $13.79 \pm 3.75$ months.

\section{Safety and tolerability of TGB treatment}

There were adverse events from treatment in $26.19 \%$ of study participants. Detailed information about adverse events is shown in Table 3.

With the exception of depression, anxiety, dizziness/vertigo, and transient diplopia, the rest of adverse events were severe and were usually associated with treatment termination.

\section{DISCUSSION}

In our study, TGB was applied as an add-on treatment in 43 patients of mean age of 39 years with long duration epilepsy with predominant severe and very frequent partial, a combination of partial and generalized or generalized tonic-clonic seizures, refractory to the prescribed, usually combined treatment with a variety of AEDs. There was relatively mild and transient dynamic improvement of seizure severity, which could not be compared with other studies for the lack of literature data. The satisfactory seizure frequency reduction we described above in $32.6 \%$ of participants, the stable mean seizure frequency reduction (40-50\%) from 6 to 24 months of the study, as well as the high and stable response rate (52.3-50\%) during the same period, are similar to the results reported in double-blind, randomized studies we found in literature ${ }^{4,13}$, and to those from some open prospective studies. ${ }^{8,9,14,15}$ Results from other open studies are quite contradictory: high percentage 
of respondents up to $94 \%$ and seizure free patients up to $75 \%$ in patients with simple partial seizures ${ }^{5-7}$, or unsatisfactory efficacy with $>50 \%$ reduction of seizure frequency in $13.2 \%$ of the participants in a retrospective study of Chahem and Bauer. ${ }^{18}$ A possible explanation of these variations is the particular features of studies design, as well as clinical characteristics of patients (different epilepsy duration and number of preceding AEDs with lacking or temporary efficacy). Investigators have not focused attention on the percentage of patients with worsened seizure control during TGB treatment, probably because of the uncertain association with drug intake in all patients. The percentage of our study participants with worse seizure control, without improvement or minimal efficacy, is not a small one (16.3\% and $51.2 \%$ respectively), and suggests focusing attention in future studies, moreover the lack of efficacy is the most frequent reason for TGB treatment termination. The appearance of new seizure types in 1 patient (myoclonic and myoclonic-atonic), especially in only 1 of them raises the question whether this phenomenon is associated with some of its mechanisms of action or is a result of the disease course. There are no similar data and a discussion of this problem in literature.

The final clinical efficacy correlates only with the number of concomitant AEDs at the study onset. Such a correlation has not been discussed in the cited literature sources. The lack of association of TGB dosage with clinical efficacy is not in conformity with results from placebo-controlled studies about a dose-dependent reduction of seizure frequency in add-on treatment of patients with refractory partial seizures. 2 Studies with more participants are needed to determine such correlation.

TGB shows acceptable safety and tolerability in our study participants with manifested adverse events in $26.19 \%$ of patients. The frequency of reported adverse events is compared to literature data, they are usually severe and become a cause of treatment termination in a similar percentage of patients - 23.3\%. ${ }^{19-21}$ Common adverse events reported in literature - dizziness/vertigo, sedation, depression, anxiety tremor, were observed in our participants as well. ${ }^{8,20,21}$ Unusual adverse events were also found in some patients - memory impairment, loss of appetite and weight, confusion, psychosis, insomnia, transient diplopia, lymphadenomegaly, rash, nausea, unstable gait, legs edema, thrombocytopenia, cervical muscles tightening. They typically result in TGB termination and necessitate attention for the possibility of manifestation in the medical practice.

\section{CONCLUSIONS}

TGB treatment is characterized with: low and transient improvement of seizure severity, good and stable reduction of seizure frequency, a possibility of worsening of seizure control, possible appearance of new seizure types, acceptable safety and tolerability. Future studies with more partic- ipants are needed with emphasis on seizure control worsening by TGB treatment, new seizure type manifestations in the course of treatment, and correlations of efficacy and adverse events from treatment with patients' demographic and clinical characteristics.

\section{REFERENCES}

1. Uthman BM, Rowan AJ, Ahmann PA, et al. Tiagabine for complex partial seizures: a randomized, add-on, dose-response trial. Arch Neurol 1998; 55: 56-62.

2. Sachdeo RC, Leroy RF, Krauss GL, et al. Tiagabine therapy for complex partial seizures. A dose-frequency study. The Tiagabine Study Group. Arch Neurol 1997; 54(5): 595-601.

3. Kalviainen R, Brodie MJ, Duncan J, et al. A double-blind, placebocontrolled trial of tiagabine given three-times daily as add-on therapy for refractory partial seizures. Epilepsy Res 1998; 30: 31-40.

4. Schachter SC, Deaton R, Sommerville K. Long-term use of tiagabine for partial seizures. Epilepsia 1997; 38(suppl.8): S105-6.

5. Chmielewska B, Stelmasiak Z. GABI-balance--a non-interventional observational study on the effectiveness of tiagabine in add-on therapy in partial epilepsy. Neurol Neurochir Pol 2008; 42(4): 303-11.

6. Niedzielska K. GEOS (Gabitril Epilepsy Observational Study) - Polish results of the international study of tiagabine in partial epilepsy. Neurol Neurochir Pol 2005; 39(6): 459-65.

7. Kozik A, Krause M. Determinants of tiagabine (TGB) efficacy and safety. A Polish multicenter study of 1307 patients with focal epilepsy. Neurol Neurochir Pol 2003; 37(3): 537-46.

8. Arroyo S, Salas-Puig J, Grupo Español de Investigación sobre Tiagabina. An open study of tiagabine in partial epilepsy. Rev Neurol 2001; 32(11): 1041-46

9. Biraben A, Beaussart M, Josien E, et al. Comparison of twice- and three times daily tiagabine for the adjunctive treatment of partial seizures in refractory patients with epilepsy: an open label, randomised, parallel-group study. Epileptic Disorders 2001; 3(2): 91-100.

10. Loiseau P. Review of controlled trials of Gabitril (Tiagabine): A clinician's viewpoint. Epilepsia 1999; 40(Suppl.9): S14-S9.

11. Richens A, Chadwick DW, Duncan JS, et al. Adjunctive treatment of partial seizures with tiagabine: a placebo-controlled trial. Epilepsy Res 1995; 21: 31-42.

12. Crawford P, Meinardi H, Brown S, et al. Tiagabine: Efficacy and safety in adjunctive treatment of partial seizures. Epilepsia 2001; 4(4): 531-8.

13. Zaccara G, Messori A, Cincotta M, et al. Comparison of the efficacy and tolerability of new antiepileptic drugs: what can we learn from long-term studies? Acta Neurol Scand 2006; 114: 157-68.

14. Jedrzejczak J. Tiagabine as add-on therapy may be more effective with valproate - open-label, multicentre study of patients with focal epilepsy. Eur J Neurol 2005; 12: 176-80.

15. Bauer J, Stawowy B, Lenders T, et al. Efficacy and tolerability of tiagabine: Results of an add-on study in patients with refractory partial seizures. J Epilepsy 1995; 8: 83-6.

16. Ganeva G, Dimova D, Kuzmanova R. Effectiveness of tiagabine in patients on treatment with one antiepileptic drug. Bulgarian Neurology (2005) 5(4): PIII21, 256-257. 9th National Congress of Neurology with international participation 08-10.09.2005, Sofia, Bulgaria.

17. Kuzmanova R. Adverse events from treatment with antiepileptic 
drugs - importance for the therapeutic approach and impact on the quality of life of patients with epilepsy [PhD dissertation], Sofia, Bulgaria: Medical University - Sofia, 2015.

18. Chahem J, Bauer J. Treatment of epilepsy with third-line antiepileptic drugs: felbamate, tiagabine and sulthiame. Nervenartz 2007; 78: 1408-12.
19. Schachter SC. Therapeutic choices and decisions. Presented at 22nd Int Epilepsy Cong Satell Symp, June 30, Dublin, 1997.

20. Schachter S. Tiagabine. Epilepsia 1999; 40(Suppl. 5): S17-S22.

21. Mula M, Sander JW. Negative effects of antiepileptic drugs on mood in patients with epilepsy. Drug Saf 2007; 30: 555-67.

\title{
Различные аспекты эфффективности тиагабина в качестве дополнительной терапии при пациентах с рефрактерной эпилепсией
}

\author{
Екатерина Витева, Захари Захариев \\ Кафедра неврологии, Факультет медицины, Медицинский университет - Пловдив, Пловдив, Болгария
}

Адрес для корреспонденции: Екатерина Витева, Кафедра неврологии, Факультет медицины, Медицинский университет - Пловдив, бул. „Пещерско шосе”№ 66, 4000 Пловдив, Болгария; E-mail: eiviteva@abv.bg; Тел.: +359887752235

Дата получения: 24 декабря 2018 Дата приемки: 30 июля 2019 Дата публикации: 31 марта 2020

Образец цитирования: Viteva E, Zahariev Z. Various aspects of tiagabine effectiveness as add-on therapy in patients with refractory epilepsy. Folia Med (Plovdiv) 2020;62(1):59-64. doi: 10.3897/folmed.62.e47762.

\section{Абстракт}

Целью данного исследования было изучение различных аспектов эффективности тиагабина (TGB) среди болгарских пациентов с лекарственно-устойчивой эпилепсией. Это открытое проспективное исследование включало пациентов с эпилепсией, которые посетили неврологическую клинику при УМБАЛ „Св. Георги“ в Пловдиве, Болгария. Пациенты заполняли дневниковые записи частоты приступов, тяжести и побочных эффектов. Были регулярные документированные визиты через 3 или 6 месяцев в течение первого года лечения TGB и через 6 месяцев или через 1 год с динамической оценкой судорог, тяжести, нежелательных явлений и данных ЭЭГ. ТГБ вводили в качестве дополнительной терапии 43 пациентам (среди которых 24 мужчины, средний возраст, которых составлял 39 лет). Наблюдалось относительно небольшое и кратковременное динамическое улучшение частоты приступов, удовлетворительное снижение частоты приступов у $32,6 \%$ участников, стабильное снижение средней частоты приступов (40-50\%) с 6 по 24 месяцы и стабильная степень ответа (52,3 -50\%) за тот же период. Новые виды судорог (миоклонические, миоклонически-атонические) возникли у 2 пациентов. Конечная клиническая эффективность была выше у пациентов с начальной монотерапией. Были установлены побочные эффекты (головокружение, седация, ухудшение памяти, потеря аппетита и веса, спутанность сознания, психоз, бессонница, преходящая диплопия, лимфаденомегалия, сыпь, тошнота, депрессия, беспокойство, тремор рук, нестабильная ходьба, отек ног, ригидность шейных мышц) у 26,19\% больных. Вывод заключается в том, что лечение TGB связано с низким и кратковременным улучшением тяжести приступов, хорошим и стабильным улучшением частоты приступов, вероятным ухудшением контроля приступов, вероятным возникновением новых типов приступов и приемлемой безопасностью и переносимостью.

\section{Ключевые слова}

тиагабин, эпилепсия, эффективность, переносимость, нежелательные явления 